\title{
Anita Grzegorzewska*
}

iD https://orcid.org/0000-0002-5923-8086

\section{Płomyczek's handbook on good manners as a manifestation of upbringing strategies under socialism}

\section{Problem specification}

Fifty years ago, Stanisław J. Paprocki delivered in London a speech entitled "Oblicza ideowe młodzieży w kraju"1 [Ideological faces of the youth of Poland]. The Polish emigrant community activist discussed with much severity the communist practices contemporary to him. Among the many objections he made, there were accusations of intentional unteaching of Poles of rational thinking, and promoting chauvinism, racism and xenophobia among the youth in order to turn them into accomplices in the authorities' fight with a fictitious enemy.

[...] the communist regime in Poland is not wasting any time. The entire party and political apparatus with the communist party at its head, the entire school and education apparatus, the three monopolistic youth organisations Z.M.S., Z.M.W. and Z.M.P. ${ }^{2}$, and the Polish Students' Association closely controlled by the regime when there are no, currently forbidden, youth ideological or political organisations, and the entire complex of mass media, such as the Polish Radio, the television, the press,

* M.A., University of Lodz, Faculty of Philology, Chair of Journalism and Social Communication; e-mail: anita.szwajkowska@uni.lodz.pl

1 S.J. Paprocki, Oblicza ideowe młodzieży w kraju: referat wygłoszony 2 grudnia 1967 r., Federacja Światowa Stowarzyszenia Polskich Kombatantów, London 1968 [unless indicated otherwise, English versions of quotations were translated from Polish].

2 S.J. Paprocki was incorrect in his enumeration of youth organisations which operated in the People's Republic of Poland (PRL) in 1967. ZMP no longer existed as it had been dissolved 11 years prior, while the group included ZHP, which he did not list. 
Polish films and theatres drenched in regime attitudes are constantly mainly targeting the young. The regime is surely quite aware of the youth's mood (this is not the German occupation!) and tries to adjust their methods of influence to politically seize the youth for their goals and purposes $[\ldots]^{3}$

Thus, argued in 1967 the long-term editor-in-chief of the National Press Bulletin at Radio Free Europe, a correspondent of the Polish Scientific Society Abroad. Significantly enough, the speech preceded by a few months the events which caused a major deterioration of the image of Poland in world, which had already been questionable. The publication of the text coincided with an extreme intensification of anti-Semitic and anti-democratic rhetoric, which revealed the socialist plan for controlling the personal development of young people. The plan, under which the education of the youth was based on instilling in them the conviction "that man is the highest social value, that he possesses development capabilities and that he can shape his own fate and the conditions of social life"4 provided that he lived and acted in line with the assumptions of the socialist system. Any diversion from the building model of socialism was met with sanctions, be it social or legal. The model itself was formulated based on the principles of Marxist philosophy where it was socially desirable to produce:

1) [...] man who builds his view of the world on scientific foundations, who can independently think, formulate and justify his views and convictions, and prove them through his actions.

2) Through comprehensively developed personality he indicates the richness of his interests and creative activeness in professional work and community engagement, in further education, and in skilfully passing his free time.

3) The correct image of the world and creative activity entail a high level of selfknowledge and the autonomy of the motivations of his behaviour. He defines himself in relation to the most highly praised values in the socialist society and in relation to constantly expanding social circles, and he can, while fulfilling various social roles, defend himself against the disintegration of his personality and become a "social force". 5

In socialism, the presence of propaganda in every aspect of social life was an undeniable fact. To shape the civil attitudes of pupils, the authorities intervened

3 Ibidem, p. 15.

4 Z. Zaborowski, Podstawy wychowania zespołowego, Państwowe Wydawnictwo Naukowe, Warsaw 1967, p. 19.

5 R. Miller, Proces wychowania i jego wyniki, Państwowe Zakłady Wydawnictw Szkolnych, Warsaw 1966, p. 32. 
in cultural life. They imposed on the youth the way in which they could spend their free time, they carefully selected their set books, films and stage plays, and they organised discussion meetings. As a result of those activities, children were supposed to crystallise a world view thanks to which they could differentiate truth from falsity, and they could learn to transform nature for the benefit of man and a perfect social life.

It is debatable whether those practices should be evaluated exclusively in negative terms, as the large discrepancy between the experience of everyday life in the People's Poland and the theory communicated by the mass media cannot entirely negate the latter. Therefore, certain doubts arise: Did the Party, which seized the right to "train" citizens obedient to it, fail to produce (either intentionally or by accident) valuable people? Was the presented content not also filled with desirable behavioural patterns? Did the media fail to promote good upbringing, the basis of which is kindness to others? Did the verification and selection of content, subject to the applicable ideology, not amplify the educational role of the media?

\section{Case study}

In the 1960 s, young readers ${ }^{6}$ could choose from only a handful of periodicals.

Table 1. Children's periodicals

\begin{tabular}{|c|c|c|c|}
\hline Title & $\begin{array}{l}\text { Frequency of } \\
\text { publication }\end{array}$ & Target group & Themes \\
\hline Miś & bi-weekly & children aged 3-6 & $\begin{array}{l}\text { Picture magazine, illustrations } \\
\text { supplemented with simple prose and } \\
\text { poetic texts. }\end{array}$ \\
\hline Świerszczyk & weekly & children aged 7-9 & $\begin{array}{l}\text { Simple poetry or prose texts about the } \\
\text { immediate surroundings of children, and } \\
\text { tales. }\end{array}$ \\
\hline Płomyczek & bi-weekly & children aged 9-12 & $\begin{array}{l}\text { Literary material, simple popular science } \\
\text { articles. }\end{array}$ \\
\hline Płomyk & bi-weekly & $\begin{array}{l}\text { children aged } \\
12-14\end{array}$ & Themes related to current events. \\
\hline Świat Młodych & Twice a week & scouts aged $10-14$ & $\begin{array}{l}\text { Articles, poems, satire, novellas } \\
\text { and novel instalments, and a rich } \\
\text { field section. For younger children, } \\
\text { a supplement entitled Zuch. }\end{array}$ \\
\hline
\end{tabular}

6 Additionally, the youth could also choose: Dookoła świata - a weekly, Filipinka - a bi-weekly, Młody Technik - a monthly, Mówiq wieki - a monthly, Na przełaj - a weekly, Nowa Wieś - a weekly, Walka Młodych - a weekly, Poznaj swój kraj - a monthly, Poznaj świat - a monthly, Radar - a monthly, Sztandar Młodych - a daily. 


\begin{tabular}{|l|l|l|l|}
\hline Młody Technik & monthly & $\begin{array}{l}\text { children aged } \\
10-15\end{array}$ & $\begin{array}{l}\text { Science and technology magazine } \\
\text { devoted to various domains of } \\
\text { knowledge: from industrial technology } \\
\text { to the automotive industry. }\end{array}$ \\
\hline $\begin{array}{l}\text { Horyzonty } \\
\text { Techniki dla } \\
\text { Dzieci }\end{array}$ & monthly & children aged 9-14 & $\begin{array}{l}\text { Articles in technology, short stories } \\
\text { about the lives of learned people. } \\
\text { Rich section with DIY projects, simple } \\
\text { experiments, easy constructions, and } \\
\text { technical titbits. }\end{array}$ \\
\hline
\end{tabular}

Source: own study.

In order to conduct a moral evaluation of the promoted models of behaviour, I analysed the content of the Płomyczek periodical. I chose the periodical due to the topics raised by the bi-weekly (Miś and Świerszczyk were too infantile) and the broad target group for which it was intended (Świat Młodych was intended for scouts, while Horyzonty Techniki dla Dzieci was intended for young DIY enthusiasts), as well as its lack of any references to current affairs, which was why it was devoid (unlike Ptomyk) of the ideological basis related to specific situations. I analysed 24 issues from 1968. At that time, the periodical's editor-in-chief was Stanisław Aleksandrzak, and it was published by Instytut Wydawniczy Nasza Księgarnia. The bi-weekly had a circulation of over 500,000 copies and a national reach.

Inside, young readers could find not only literature sensu stricto (novels in instalments, short stories, tales, fairy tales and poems) and quasi-literary texts (fictionalised reports), but also purely journalistic texts. The periodical introduced the first column forms ${ }^{7}$, a popular science section, and small items of news. It also featured much fictionalised news with commentary and letters from readers. The section of brain twisters was also rich; it included: riddles, charades, puzzles, crossword puzzles, sometimes descriptions of games and plays, song lyrics with notes, and picture stories. While fulfilling its educational, aesthetic and entertainment functions, the periodical evolved towards popular periodicals in which the prerequisite of being current consisted of celebratory texts related to the rhythm of a syncretic calendar: natural, anniversary/historic, and school calendars. ${ }^{8}$ In line with state policy, Płomyczek did not publish any content related to Catholic holidays, thus promoting the liberation of the mind from religious prejudice and superstitions. In following the social and moral changes which caused the loosening of family bonds ${ }^{9}$, the order of the family calendar was also rejected (exclusion of Children's Day, Mother's Day, Grandma's Day, etc.)

7 W. Gust, Płomyczek, Płomyk i Świat Młodych jako środki dydaktyczne w procesie kształcenia językowego w szkole podstawowej, Centrum Doskonalenia Nauczycieli, Poznań 1990, p. 11.

8 B. Olszewska, Literatura na łamach „Płomyczka” (1945-1980), Uniwersytet Opolski, Opole 1996, p. 14.

9 Ibidem, p. 138. 
Plomyczek strived to control the behaviour of the young generation by promoting the model of democratic upbringing, based on the socialist principles of coexistence. Similarly to other periodicals intended for children, it fulfilled the function of a social upbringing institution ${ }^{10}$ shaping the characters and world views of its readers. It combined content used for patriotic and moral education with propaganda motifs. Propaganda tones resonated loudly both in the selection of the content and its presentation. Some obvious examples of manipulating young minds included: aggressive promotion of the Soviet Union (issue 3: article about the EXPO fair in Montreal; issue 15: the achievements of engineers in telecommunications), promotion of other socialist states (issue 5: entire issue devoted to Yugoslavia), and pompous celebration of state holidays (issue 6: Victory Day; issue 14: the National Day of the Rebirth of Poland; issue 19: entire issue devoted to the 25th anniversary of the Polish People's Army). Indoctrination efforts also echoed in the never-fading memories of the Second World War, e.g. texts devoted to the genocide conducted in Polish villages, with particular focus on the atrocious murders of children.11 What seems excessive was not only the intention to shock with the atrocities of the war, but also the exaggerated pompous style:

Podczas drugiej wojny światowej w Warszawie zginęło ponad 700 tysięcy ludzi, a miasto, zburzone w czasie walki i spalone przez hitlerowców po zakończeniu działań wojennych, przedstawiało obraz ruin i gruzów. Taki właśnie, jak widzicie na naszej fotografii. Wy tego zniszczenia nie widzieliście, ale wiedzieć o nim i pamiętać musicie.

[...] musicie też wiedzieć i pamiętać, że Warszawę z ruin i gruzów dźwignęły i odbudowały ręce naszych robotników i inżynierów, ręce tysięcy murarzy przy wspólnym wysiłku całego narodu.

[During the Second World War, over 70o,ooo people died in Warsaw. After being turned to rubble during the fighting and burnt down by the Nazis after the war efforts had ended, it was a landscape of ruins and rubble. Just as you can see in the photograph. You did not see that destruction, but you must know and remember about it.

[...] you must also know and remember that Warsaw was raised from ruin and rubble and rebuilt by the hands of our workers and engineers, the hands of thousands of masons in a joint effort of the entire nation. $]^{12}$

10 J. Papuzińska, Wychowawcza rola prasy dziecięcej, Państwowe Wydawnictwo Naukowe, Warsaw 1972, p. 70.

11 Płomyczek featured, side-by-side, infantile short stories or light reportages and mature realistic fiction.

12 Płomyczek 1968, issue 18. 
Texts devoted to the Polish United Workers' Party (PZPR) were another manifestation of propaganda that should be mentioned. Here are a few examples:

Pracownicy stoczni polskich dla uczczenia V Zjazdu Polskiej Zjednoczonej Partii Robotniczej podjęli zobowiązania przyśpieszenia produkcji.

[To celebrate the 5th Congress of the Polish United Workers' Party, the shipyard workers made a commitment to accelerate production. $]^{13}$

Partia jest siłą kierowniczą całego narodu i jego przewodnikiem. To jakby lokomotywa prowadząca pociąg, w którym jesteśmy my wszyscy.

[The party is the directing force of the entire nation and its guide. It is like a locomotive leading a train, and we are all on board. ${ }^{14}$

Chcemy wyrazić swoje podziękowanie dla Partii i Rządu za piękną, nowoczesną szkołę.

[We wish to express our thanks to the Party and the Government for a beautiful modern school. $]^{15}$

The main goal of the media, enforced completely by the authorities, was to influence the general opinion and convince recipients to assume the socialist attitude. Periodicals and radio and television shows intended for children combined the educational and entertainment purposes with the persuasive function. Their task was to shape young people into responsible participants of the collective life of the PRL. That influence was obvious, though one should remember that the content not only included propaganda, but was also filled with ideologically neutral basic devices of educational influence. They defined the whole of the proper behaviour in professional, neighbourly and friendly contacts, and the approach to others and strangers in everyday situations. That also applied to Płomyczek which, apart from promoting socialist doctrines, promoted ideologically neutral upbringing models and those will be the focus of my study.

\section{Upbringing strategies}

Under the notion of upbringing strategies, I understand the conscious selection of the themes presented in Płomyczek used for shaping the desired system of broadly understood moral values. That framing of the term diverges significantly from

\footnotetext{
13 Płomyczek 1968, issue 18.

14 Płomyczek 1968, issue 23.

15 Płomyczek 1968, issue 11.
} 
the socialist definition in which upbringing strategies were supposed to lead to a complete acceptance of communist perspectives of the dynamic development of the People's Republic of Poland.

The socialist upbringing strategy was a system of purposeful, planned and intentional activities having a major significance on the shaping of fundamental views, convictions, attitudes and values, which have a deciding significance on the shape of a person's personality, and which are related to the society-related needs of the social system in its individual stages of development. ${ }^{16}$

The above definition suggests that the Party-controlled process of raising the young generation did not cover the teaching of culture and basic good manners. However, to the contrary, the media of the PRL promoted kindness towards others, equality among people, respect for the dignity of both oneself and others, responsible approach to work, and the strive for creating a good atmosphere among friends. The notion of personal culture included also knowledge of various domains of life promoted among the youth: literature, history, art and technology. ${ }^{17}$

It appears that, if one were to strip Płomyczek of its socialist doctrine, the periodical would resemble a timeless universal guide on good manners. The notions and principles of proper behaviour promoted in it covered a series of ethical attitudes considered fundamental in relations with other people. ${ }^{18}$ I classified them under three categories: respect, kindness, and knowledge.

\section{Respect principle}

The respect principle is one of the universal principles which has led humanity since prehistoric times. ${ }^{19}$ It covers such "lesser" norms of good manners as: tolerance, respect for one's privacy, discretion, and punctuality. It is the kind of politeness which belongs to everyone. Disrespecting another person is always a violation of good manners or even the elemental principles of humanity.

In Płomyczek, the motif of respect assumed various forms. It was present in literary and quasi-literary texts, as well as in every type of journalistic content. Young readers learnt that respect is due to older people, women, people who have

16 W. Pomykało, Socjalistyczna strategia wychowawcza, Wydawnictwo Ministerstwa Obrony Narodowej, Warsaw 1973, p. 10.

17 In 1968, the Chief Council of Educational Programs at TVP began broadcasting a show: lessons in civil education.

18 T. Orłowski, Protokół dyplomatyczny, Polski Instytut Spraw Międzynarodowych, Warsaw 2010, p. 82.

19 Ibid., p. 84 . 
fought against the enemies of the state, teachers, and public figures, including politicians, doctors and artists. Those texts where a seemingly "normal" person, not outstanding in everyday life, often not devoid of various flaws, eventually proved to be someone important and worthy of respect were typical for this motif.

The "Ostatni posterunek" [Final post] short story showed how expansive the category of the so-called 'persons of merit' was. Józef Walenda, a janitor, ignored by all pupils, was eventually revealed to have been a corporal who participated in the assault on Berlin. Only after being recognised during a school celebration by Jan Rózga, a former comrade in arms, did he have a chance to tell the children the extraordinary story of his life.

Popłynęła opowieść najciekawsza, jaką kiedykolwiek słyszeli, opowieść o wielkim żołnierskim trudzie, o dzielności i poświęceniu, o koleżeństwie, niezłomnej wierze w zwycięstwo i wreszcie o samym zwycięstwie.

[They listened to the most interesting story they had ever heard, a story of a huge soldierly effort, about bravery and sacrifice, about camaraderie, unrelenting faith in victory and, finally, about the victory itself. $]^{20}$

That event helped the pupils realise that all soldiers deserved respect regardless of whether, in the fight for freedom, they fulfilled the leading functions or were just minor participants. A similar moral was offered by short stories in which nameless workers and peasants, through their work for the good of the Nation, gained respect in the eyes of school children. The community-focussed thinking was the basis of yet another text, in which admiration applied to a great artist despite his being an extremely absent-minded person.

Przestaliśmy się śmiać i rozmawiać. Zadarliśmy ku górze głowy i - w skupieniu - słuchaliśmy czarodziejskich skrzypiec. Trudno było uwierzyć, że to gra ten sam pan Smyczek, który nosi otwarty parasol przy pogodzie i śpi we fraku. A jednak to była prawda. Słuchaliśmy więc tej muzyki i myśleliśmy, że podlewanie sztucznych kwiatów nie przynosi ujmy, jeśli się tak cudownie gra na skrzypcach.

[We stopped laughing or talking. We peered up and, in silence, we listened to the magical violin. It was hard to believe that the person who was playing was the same Mr. Smyczek [Mr. Fiddlestick] who would carry an open umbrella in fair weather or sleep in his tailcoat. And yet that was the truth. So, we listened to the music and we thought to ourselves that watering plastic plants does not discredit someone if they play the violin so wonderfully. $]^{21}$

20 Płomyczek 1968, issue 19.

21 Płomyczek 1968, issue 11. 
That amusing story taught children good manners and also, which was typical for the PRL, it showed them the path for personal development, as no one reproached the characters for making jokes at the musician - the boys themselves noticed how inappropriate their behaviour was.

Płomyczek short stories argued that respect for older people was based on the respect for their life experiences. They made children aware of the fates of lonely people and encouraged them to offer neighbourly aid. They taught them to trust and be kind to others and warned them against jumping to unfounded conclusions about strangers. They also combated, as indicated in the following example, the practise of parents scaring children with older and lonely people. The "Baba Kata" short story revealed the educational backwardness of mothers and fathers who made their children believe that an elderly woman living in the suburbs was a witch. Younger children were taken aback with fear, older ones picked on the woman. The protagonist of the short story had similar feelings until the elderly woman helped the girl find her way back home during a blizzard.

Moje oczy zetknęły się ze spojrzeniem baby Katy, która patrzyła na mnie, jakby czegoś ode mnie oczekując. I nagle w oświetleniu lampy naftowej ujrzałam tę twarz taką, jaką w istocie była. Dobrą, łagodną i strasznie smutną. Znikł gdzieś strach przed garbatą staruszką. Przytuliłam mocno swoją zziębniętą twarz do jej kolan, które pachniały jabłkami i pigwami. Od tamtego dnia często dostawałam od niej jabłka.

[My eyes met the sight of baba Kata, who was looking at me as if she was expecting something of me. And suddenly, in the light of the kerosene lamp, I saw that face as it truly was. Kind, subtle and terribly sad. Suddenly, the fear of the hunched old lady vanished. I hugged her tightly pressing my cold face to her knees, which smelled of apples and quince. From that day, I often got apples from her.] $]^{22}$

The notion of respect inseparably entailed the principle of respecting one's privacy. Płomyczek condemned all forms of meddling in other people's lives. It warned against fingering, quite popular in the PRL; it recommended caution in revealing other people's secrets, and it did not commend spying even for a noble cause, not to mention for pure curiosity, as in the short story "Tajemnica Pana Gołąbka" [Mr. Gołąbek's Secret], where two pupils watched a retired teacher. It eventually turned out that he was giving secret private lessons to failing students.

Bo oto w cichym, uśpionym budynku szkolnym zaczęła się niezwykła lekcja. Prowadził ją pan Gołąbek, nauczyciel stary jak świat, który nie mógł żyć bez szkoły 
i przychodził do niej wieczorami, żeby pomagać słabszym uczniom. Schylał się nad nimi troskliwie i cierpliwie tłumaczył im tajniki zadań tekstowych i zawiłe zasady pisowni.

[There, in the quiet dormant school building, an exceptional lesson started. It was conducted by Mr. Gołąbek, a teacher as old as the world, who was not able to live without school and came to it in the evening to help failing students. He worked with them with care and patiently explained to them the secrets of textual problems and the complicated rules of spelling.] $]^{23}$

When Mr. Gołąbek's secret came out, the boys were seized by a huge sense of shame and they felt as if they had betrayed him. The best pupil in class got into even greater trouble as he mindlessly, without getting to know the whole truth, publicly revealed the history of a new boy in class by writing on the blackboard:

Czy wiecie, kim jest Pituła? Chuliganem i wagarowiczem! Przenieśli go karnie z innej szkoły, bo za dużo rozrabiał. Teraz u nas próbuje...

[Do you know who Pituła is? A hooligan and a truant! He was relocated as a punishment from another school because he was making too much trouble there. Now he's trying that here... $]^{24}$

In fact, the troublemaker was a good child, and only through his family problems did he lose his way for a moment, and the hostile attitudes of his new peers did not help him straighten up. The short story offers an excellent example of how empty talk can destroy someone's life. The detrimental influence of gossip on interpersonal relations was also raised by epigrams:

Tęgi z Jacka „matematyk”, wciąż do plotek ma tematy.

[Jacek is quite the "mathematician",

he continues to have topics to gossip on. $]^{25}$

Epigrams also became a weapon in the fight with the lack of punctuality:

Kiedy spóźniam się do szkoły,

każą mi się wstydzić.

A że pierwszy wciąż wychodzę,

tego nikt nie widzi.

23 Płomyczek 1968, issue 22.

24 Płomyczek 1968, issue 18, 19.

25 Płomyczek 1968, issue 2. 
[When I come late for school,

I should be ashamed of it.

But when I leave first,

No one sees me do it. ${ }^{26}$

Though it often seems a trivial matter, punctuality is a major element of good manners. Płomyczek presented it as the attribute of mature and sedate people. "Punctuality is commonly, and quite incorrectly, associated with avoiding being late. In reality, punctuality also means not coming too early." ${ }^{27}$ Unless in exceptional circumstances:

Tak, u dziadka - maszynisty wszystko musiało być ściśle według rozkładu. Nawet kanapki, jabłka i czekolada. Tyle że na stację dziadek nie przyszedł punktualnie. Pierwszy raz w życiu sprzeniewierzył się rozkładowi jazdy. Był tam już o całe pół godziny wcześniej. Na wszelki wypadek. Żeby nie spóźnić się po wnuka.

[Yes, at grandpa's, the locomotive driver, everything had to be to a strict timetable. Even sandwiches, apples and chocolate. But grandpa did not come to the station on time. For the first time ever, he violated the timetable. He was there a whole 30 minutes early. Just in case. So that he would not be late for his grandson. ${ }^{28}$

Even though punctuality is sometimes referred to as "the politeness of kings", children learnt that it applied to everyone, both old and young, superiors and subordinates. If a person arrives at a meeting at the agreed time, it means they respect the person whom they were supposed to meet, and it proves their dependability and reliability. ${ }^{29}$

The biggest display of respect for another person is to respect their convictions, beliefs and customs, as well as being tolerant of their weaknesses and imperfections. Originally, tolerance was associated with consent to the practice of a selected religion. "That is how it was understood by the lawmakers in the Sejm when in 1573 they passed one of the first acts of religious tolerance in Europe: the Warsaw Confederacy." ${ }^{30}$ Nearly 400 years later, the Polish government violated the principle by spurring in March 1968 the darkest of forces dormant in the society: intolerance, anti-Semitism, racism and extreme nationalism. During a session of the Sejm in April 1968, Jerzy Zawieyski strongly objected to those practices proclaiming the Christian vision of dialogue, a condition of which is "an attitude of respect for other

\footnotetext{
26 Ibidem.

27 T. Orłowski, op. cit., p. 91.

28 Płomyczek 1968, issue 8.

29 T. Orłowski, op. cit., p. 90.

30 Ibid., p. 88.
} 
people's differences, the willingness to understand other people's reasons, a special kind of transcendence onto another person whom we do not wish to absorb, seize or change, but with whom we wish to seek out something."31 Acceptance, thus understood, means completely safe consideration of someone else's otherness, which does not necessarily have to mean supporting it.

As one might had expected, Płomyczek during the anti-Semite campaign refrained from publishing texts which openly encouraged people to respect different views, inclinations or convictions. One exception was a reportage from a January issue, i.e. prior to the massive propaganda attack on people of "Stalinist" or "Jewish" roots. The article discussed the fortunes of a Roma family which settled in the village Zaborze. The Roma, accepted warmly by the local population, having rejected their nomadic lifestyle, started living according to the norms and rules applicable in the village. They took up jobs and their children went to school. Despite the change of their lifestyle, they did not forget their traditions and customs. The youngest taught their friends in Zaborze how to dance like the Roma do, while the black-bearded Bazyl gave rides to all the children to the school located 3 kilometres away on a horse-pulled Roma wagon.

Bazyl powozi. Czarną brodę pobielił mu śnieg, ale stary Cygan jest zadowolony. Kłania się z dumną miną spotkanym po drodze znajomym i nieznajomym, jakby chciał powiedzieć: „A co? przydał się na coś stary cygański wóz?”.

[Bazyl was driving. His black beard became white from the snow, but the old Gypsy was pleased. He nodded proudly to passing friends and strangers as if trying to say:

"Well, now. The old gypsy wagon did come in handy after all."] $]^{32}$

The respect principle was also one of the most emphasised principles in Ptomyczek and one of the least used in everyday life in the PRL. Young people, taught how to critically assess their reality, noticed that they happened to be living in conditions far from those promoted in the periodical. They noticed that the humanistic attitude instilled in them, which consisted of respect for others, was only applied in relation to people who followed the socialist system of values.

\section{Reciprocity principle}

Prawdziwie dobre wychowanie - jak słusznie zauważą Konstancja Hojnacka, autorka „Kodeksu towarzyskiego” - to nie szereg wyuczonych gestów codziennych, to nie bezduszna tresura, ale przede wszystkim na wskroś życzliwe ustosunkowanie

31 A. Radziwiłł, W. Roszkowski, Historia 1956-1997, Wydawnictwo Szkolne PWN, Warsaw 2000, p. 126.

32 Płomyczek 1968, issue 2. 
się do ludzi, wyrażające się w przestrzeganiu tego, aby nikt w naszej obecności, a zwłaszcza z naszego powodu, nie doznał przykrości.

[Truly good manners, as Konstancja Hojnacka, the author of Kodeks towarzyski, aptly noted, do not only consist of a series of acquired everyday gestures nor mindless training, but rather an utterly kind approach to people expressed through one's making sure that no one in one's presence, especially because of one, would experience any distress. $]^{33}$

Respect is part of the notion of personal culture, while kindness belongs to the culture of the heart. Presumably that is why it is so rarely discussed in handbooks on good manners. While politeness, tact and courtesy are treated as components of etiquette; goodness, kindness and cordiality remain within the domain of the conscience. The reciprocity principle covers both. Its core has been perfectly grasped in Aleksander Fredro's maxim: "do not do to others what is unpleasant to you" often understood in reverse. ${ }^{34}$ That was why examples which illustrated "such behaviour towards others which one would expect to be used towards them" 35 are rare both in the real world and on the pages of Płomyczek.

An excellent example of selfless care for another person was provided in a Yugoslavian story "Meeting in a clearing". A young partisan met a tired elderly woman at the break of dawn seeking her son. She helped the woman by indicating the place where the boy was. However, before the woman went on her way to the partisan camp where her child was, she devoted her time to the girl giving her a mother's love.

Staruszka popatrzyła na mnie, patrzyła, a potem zaczęła głaskać mnie po twarzy i po rękach. Zdjęła mi z głowy czapkę partyzancką, rozplątała jasne warkocze i, wyciągnąwszy z kieszeni grzebień, zaczęła mi rozczesywać splątane pasma włosów. [...] Masz, tu są jeszcze orzechy i serek wędzony - staruszka wtykała mi w ręce i do kieszeni prezenty przeznaczone dla syna. A ja stałam speszona i było mi tak ciepło w sercu jak nigdy.

[The old lady looked at me, she stopped, and then started stroking my face and hands. She took my partisan hat off my head; she untangled my light braids and with a comb she took out of her pocket she began combing the tangled strands of my hair. [...] Here, have these nuts and smoked cheese," the old lady pushed the gifts

33 As quoted in: M. Barbasiewicz, Dobre maniery w przedwojennej Polsce, Wydawnictwo Naukowe PWN, Warsaw 2012, p. 14.

34 T. Orłowski, op. cit., p. 82.

35 Ibidem, p. 82. 
intended for her son into my hands and pockets. And I stood there bemused and felt such a warmth in my heart as never before.] ${ }^{36}$

Care and motherly love were motifs often used in Płomyczek. Older, often lonely, women were the positive characters of many stories and fairy tales. They protected the hearth and home, they offered support and aid to those who needed it, and they even, as in the legend Sunken city, protected people against destruction.

According to a story told for many a century, where now there is a lake near the town of Pszczew, there once lay a rich city. Its inhabitants denied a poor tired wanderer shelter or food. It was only an old lady who lived alone on the outskirts of the city that shared her food with him. In reward, the old man gave her a beautiful expansive linden and warned her that as long as the tree lived, the city would exist. After the old lady's death no one watered the tree even though she often reminded the people about the consequences of neglecting that obligation.

I tylko czasem starzy ludzie w tamtej okolicy, gdy zaczną się wsłuchiwać w ciszę wieczorną - twierdzą, że słyszą bicie dzwonów w jego kościołach i gwar rozmów na podwodnych ulicach.

[And only sometimes old people from those parts, when closely listening to the evening silence, claim they can hear the city's church bells ringing and the buzz of the voices in the streets under water. ${ }^{37}$

From the very first handbook on good manners by Giovanni della Casa ${ }^{38}$, all such codes outlined etiquette as a series of rules which should be observed in interpersonal relations. However, those do not cover people's approach to animals. One exception was "Płomyczek's handbook on good manners." ${ }^{9}$ In almost every issue from 1968, there were texts which promoted animal care. Even though in their case it would be difficult to talk about the classical reciprocity principle, I believe that the significance of the problem entitles me to indicate at least a few examples.

Płomyczek's readers wrote letters to the editors about how they took care of birds in winter:

36 Płomyczek 1968, issue 5.

37 Ptomyczek 1968, issue 2.

38 In 1550-1555, Giovanni della Casa, Papal nuncio to Venice, wrote to his friend Bishop Galeazzo Florimonte about the ethical principles which every human should follow. The correspondence was first published in 1558 as Galateo ovvero de'costumi.

39 I used this symbolic manner to define the content of Płomyczek, removing from it the set of socialist views. 
Zrobiliśmy dużo domków dla ptaków i zawiesiliśmy je na drzewach przy szkole i w parku.

[We made many bird houses and we hung them in trees by the school and in the park.] ${ }^{40}$

Children maintained rest houses for forest and field creatures, and they took care of their safety, e.g. by taking them out of snares. Even the son, according to "Krakowska legenda"41 [Krakow legend], of King Casimir IV Jagiellon bought birds from the hands of fowlers to set them free.

Even the biggest urchins had sympathy for animals:

Bliźniacy coś knują. To jest pewne. Inaczej nie mieliby takich tajemniczych min. Jeśli się idzie z taką tajemniczą miną do lasku, to na pewno ma się jakieś niecne zamiary. Zresztą bliźniacy broją codziennie. [...] Gaweł sięga do kieszeni i wyjmuje z niej niewielki, prostokątny kartonik. Podchodzi z nim do grabu i wyciąga rękę w stronę gniazda. Pisklęta ufnie otwierają dziobki, matka przeskakuje z gałęzi na gałąź... Gaweł tymczasem wspina się na palce i - wiesza kartonik tuż pod gniazdem. Potem jeszcze raz odczytuje wykaligrafowany na kartoniku napis: „Gniazdo jest pod naszą opieką. Biada temu, kto by je zniszczył! Paweł i Gaweł”.

[The twins are up to something. That's for sure. Otherwise their faces would not be so mysterious. If you go with such a face to the woods, you surely have some despicable intentions. In fact, the twins are up to mischief every day. [...] Gaweł reached into his pocket and took out a small rectangular piece of cardboard. He came with it closer to the hornbeam and reached towards a nest. The baby birds opened their beaks trustingly, the mother jumped from branch to branch... While Gaweł tiptoed and hung the piece of cardboard right underneath the nest. Afterwards, I once again read the carefully written sign: "This nest is under our care. Woe betide him who destroys it! Paweł \& Gaweł.”] ${ }^{42}$

Coming back to interpersonal relations: patterns of behaviour, especially the moral norms expressed in the various models promoted in Płomyczek, taught children how to establish and develop proper interpersonal contacts. However, the texts more often condemned any instance of indifference to others than explained that one should reciprocate for something one received. The need to reciprocate either the smallest of gestures or time spent was not a popular theme raised in the periodical during the period of the minor stabilisation.

40 Płomyczek 1968, issue 3.

41 Płomyczek 1968, issue 3.

42 Płomyczek 1968, issue 11. 


\section{Open mind principle}

In line with the principle that every researcher may propose a convention when defining a term or classes of objects which they intend to discuss, I developed this division which covers three basic sets of elements which, when combined, ensure good manners. I decided that apart from the commonly discussed principles (respect, reciprocity), knowledge should also be included. The open mind principle in my understanding constitutes one of the pillars of good manners combining all human strivings to expand their mental horizons. That includes gathering, maintaining and skilful utilisation of extensive general knowledge in various fields. A well-manner person is someone well read, and who, in various social situations, can initiate and manage a conversation on interesting, non-controversial topics. Similar conclusions could be drawn from reading contemporary codes of good manners, the authors of which stress the major role of conversation. ${ }^{43}$

Płomyczek, associated with school education and the curriculum, did not avoid scientific issues. Even a semantic analysis of the title, which emphasised the motif of fire and light, underlined the informative function of the periodical. Fixed sections (A to ciekawe! [Now that's interesting!]; Kacik ciekawej książki [Interesting book corner]; Nasz kraj, nasza ojczyzna [Our country, our homeland]), and the frequent mentions, reports, accounts, bio-sketches, reportages, interviews, letters to the editors and answers to them, and journalistic photography were devoted to expanding the general knowledge of young readers. The themes, matching the general trends and focus of the time, covered a wide range of news, which, for clarity of description, I classified into categories with illustrative examples.

\section{Interesting facts about this issue}

From the September issue, pupils could learn that school years around the world did not begin on the same day as in Poland. And so: in Indonesia, children start the school year on 1 January, in Brazil on 1 March, in Japan on 1 April, in India on 15 July, and, in Afghanistan, holidays are related to a moving holiday and occur at different times each year. ${ }^{44}$ The April issue included a short note on unique holidays celebrated that month. In Ypern there is a cat holiday, while in Nice, appropriately to the name of the month, there is a flower holiday [in Polish the name of the month of kwiecien (April) was derived from the blooming flowers (kwiaty in Polish)].45

43 Cf. P. Kuspys, Savoir-vivre. Sztuka dyplomacji i dobrego tonu, Zysk i S-ka Wydawnictwo, Poznań 2012, pp. 85-87.

44 Płomyczek 1968, issue 17.

45 Płomyczek 1968, issue 7. 
2. Interesting facts from around the world

In the vein of unique customs, it seems worth mentioning an illustrated reportage entitled "Co ludzie noszą na głowie?" [What do people carry on their heads?] It presented the unique way of carrying loads. ${ }^{46}$ Even more exotic are the tombstones of the Malagasy people from Madagascar. There are figures in the shape of people, animals or even vehicles placed on carved colourful columns. ${ }^{47}$

\section{Earth in the cosmos}

The 196os marked the birth of the space age. Płomyczek, up to date with current news, published the first colour photograph of the entire Earth made by an American satellite. ${ }^{48}$ Three months later, it reported on the first flight of a human in space thus celebrating Yuri Gagarin, who had died in a tragic accident. ${ }^{49}$

4. Natural environment - interesting facts in geography Young readers could learn that volcanoes were dangerous and yet very beneficial. Weathered lava constitutes extremely fertile soil in which the most demanding plants can be cultivated. Additionally, some rocks of volcanic origin include gold, platinum and precious stones. And one more interesting fact from the issue: The Okawanga River is the only river with an estuary in the hot sands of a desert..$^{50}$

5. Natural environment - plants

Here are a few details about record-breaking plants: the oldest and the largest trees on Earth (reaching 150m in height and living 4,000 years) are Californian sequoias, ${ }^{51}$ while the sweetest plant in the world grows in Nigeria: a red berry $(1,500$ times sweeter than sugar). ${ }^{52}$

6. Natural environment - animals

That section also provided readers with a handful of interesting facts: the koala bear never drinks water ${ }^{53}$, in Kazakhstan there are 26 species of ants ${ }^{54}$, storks

\footnotetext{
46 Płomyczek 1968, issue 8.

47 Płomyczek 1968, issue 7.

48 Płomyczek 1968, issue 2.

49 Płomyczek 1968, issue 8.

50 Płomyczek 1968, issue 20.

51 Płomyczek 1968, issue 14.

52 Płomyczek 1968, issue 19.

53 Płomyczek 1968, issue 18.

54 Płomyczek 1968, issue 2.
} 
sleep in flight ${ }^{55}$, herrings have the best hearing among all fish ${ }^{56}$, while the tails of Japanese cocks reach up to 7 metres in length. ${ }^{57}$

\section{Industry}

Various articles arguing that children could be proud of the fuel and power industry as Poland ranked 6th in the world in terms of exploitation of black coal. ${ }^{58}$ Also the food industry, confectionery in particular, guarantees a good position in the market. Each year, we export 9,00o tons of chocolate for a total sum in excess of 11 million zlotys. ${ }^{59}$

8. Technological novelties

One more piece of information about sweets, this time rather unique: in Japan sugar was produced out of crude oil. ${ }^{60}$ And, in contrast, a piece of news on an invention constructed by the English which became popular: an electronic thermometer which measures temperature at the touch of skin. ${ }^{61}$

\section{Large constructions}

Płomyczek informed young readers not only about how the infrastructure of Polish towns and villages was changing, but also offered them knowledge about foreign investments. Among the many examples, two were most noteworthy. Those were the water system in Libya being built by Polish engineers and workers, ${ }^{62}$ and the utopian vision of a town in Siberia which was supposed to be enclosed under a huge dome to protect the inhabitants against the cold. ${ }^{63}$

10. Cars

Płomyczek eagerly promoted the Polish automotive industry, discussing in detail the manufacturing process and the advantages of Fiat ${ }_{125} \mathrm{P}$ passenger cars ${ }^{64}$, STAR trucks ${ }^{65}$ and Ursus tractors ${ }^{66}$.

\footnotetext{
55 Ibidem.

56 Płomyczek 1968, issue 8.

57 Płomyczek 1968, issue 16.

58 Płomyczek 1968, issue 23.

59 Płomyczek 1968, issue 13.

60 Płomyczek 1968, issue 22.

61 Płomyczek 1968, issue 3.

62 Płomyczek 1968, issue 7.

63 Płomyczek 1968, issue 3.

64 Płomyczek 1968, issue 18.

65 Płomyczek 1968, issue 10.

66 Płomyczek 1968, issue 13.
} 


\section{Sport}

The theme of sport, due to the 1968 Olympic Games, was present in nearly every issue of the periodical. It included descriptions of new sporting disciplines ${ }^{67}$, information on specific athletes ${ }^{68}$, and discussions of past tournaments and the medals won ${ }^{69}$. Most texts were of an information-educational nature:

Zastanówcie się przez chwilę nad tym, co pisaliśmy o sportowcach, nad ich umiejętnością walczenia $\mathrm{z}$ różnymi słabościami - z chorobą, z przeciwnikiem. Chciałbym, abyście w swoim życiu wzorowali się na magistrze Waldemarze Baszanowskim, na Józefie Szmidcie, i równie jak oni uważnie podchodzili do swoich obowiązków w szkole i na boisku. A wówczas, za parę lat, może i Wy staniecie się bohaterami Igrzysk Szkolnych, Igrzysk Olimpijskich.

[Consider for a moment what we wrote about athletes, and their ability to combat various weaknesses - illnesses, their opponents. I would like you to follow in your lives the examples of Waldemar Baszanowski, M.A. or Józef Szmidt and just like them approach your duties at school and in the field with attention. And then, in a few years' time, maybe you too will become the heroes of a School Olympiad or the Olympic Games. $]^{70}$

\section{Literature}

Every other week, the authors of the "Kącik ciekawej książki" section recommended several titles to young readers. Most common were books by Polish authors, in which both boys and girls could find something interesting. Apart from the "Ważne sprawy dziewcząt i chłopców" [Important issues for girls and boys] series, the section was filled with reviews of historical novels, adventure novels, novels of manners, travel novels, and war novels, fairy tales, fables and legends for younger readers. Płomyczek encouraged its readers to read poems, and it also inspired them.

The educational and upbringing strategy of Płomyczek, which consisted of a scientific recognition of the world, was supposed to ensure a diverse development of children. The periodical educated enterprising creative young people, curious about the world not only "through learning and playing", but also by clearly defining requirements for them, and it was unbefitting to not meet those:

Chcę, żebyś wiedział Przyjacielu,

Ty, Który czytasz ten „Płomyczek”,

że spośród Czytelników wielu

67 Płomyczek 1968, issue 3.

68 Płomyczek 1968, issue 9, 11, 15, 16.

69 Płomyczek 1968, issue 14, 20.

70 Płomyczek 1968, issue 18. 
na Ciebie przede wszystkim liczę.

[...]

Lecz, pamiętajcie, Przyjaciele,

Wy, co „Płomyczek” ten czytacie,

że się spodziewa po Was wiele

Polska - Największy Wasz Przyjaciel.

[I want you to know, my Friend,

You, who are reading this Płomyczek,

that among the many Readers

I count on You the most.

[...]

But remember, Friends,

You who read Płomyczek,

that much is expected of You

by Poland, Your Greatest Friend.] ${ }^{71}$

\section{Conclusion}

"In the project of raising "the new man", from the very start the communist authorities had assigned a major role to public communication."72 The analysis of the content of Plomyczek indicated that the activity of managing the development of the young generation occurred at two functionally different ethical levels: at an engaged level and an ideologically neutral level. On the one hand, the content of the periodical prepared young people to actively participate in social and political life. It developed in young readers attitudes which led to the acceptance of socialist perspectives of the development of both the country and individuals. On the other, it promoted timeless moral values by teaching culture and the principles of good manners.

A separate discussion applies to content which shaped patriotic attitudes based on an affirmative approach to the existing reality. In order to be able to discuss the influence on the periodical's readers as a whole, it would be necessary to extend the analysis to include such topics as: the heroic struggle for liberation, sacrifice for the good of the homeland, the glory of the Polish People's Army, the progressive nature of tradition, and the extent of remarkable achievements in culture, science and industry. The "trend" for patriotism in the era of the minor stabilisation remains to be studied.

71 Płomyczek 1968, issue 14.

72 K. Kunicki, T. Ławecki, Kronika PRL 1944-1989. Wychowanie w szkole i w domu, vol. 20, Bellona SA, Warsaw 2016, p. 94. 


\section{Bibliography}

Barbasiewicz M., Dobre maniery w przedwojennej Polsce, Wydawnictwo Naukowe PWN, Warsaw 2012.

Gust W., Płomyczek, Płomyk i Świat Młodych jako środki dydaktyczne w procesie kształcenia językowego w szkole podstawowej, Centrum Doskonalenia Nauczycieli, Poznań 1990.

Kunicki K., Ławecki T., Kronika PRL 1944-1989. Wychowanie w szkole i $w$ domu, vol. 20, Bellona SA, Warsaw 2016.

Kuspys P., Savoir-vivre. Sztuka dyplomacji i dobrego tonu, Zysk i S-ka Wydawnictwo, Poznań 2012.

Miller R., Proces wychowania i jego wyniki, Państwowe Zakłady Wydawnictw Szkolnych, Warsaw 1966.

Olszewska B., Literatura na łamach „Płomyczka” (1945-1980), Uniwersytet Opolski, Opole 1996.

Orłowski T., Protokół dyplomatyczny, Polski Instytut Spraw Międzynarodowych, Warsaw 2010.

Paprocki S.J., Oblicza ideowe młodzieży w kraju: referat wygłoszony 2 grudnia 1967 r., Federacja Światowa Stowarzyszenia Polskich Kombatantów, London 1968.

Papuzińska J., Wychowawcza rola prasy dziecięcej, Państwowe Wydawnictwo Naukowe, Warsaw 1972.

Pomykało W., Socjalistyczna strategia wychowawcza, Wydawnictwo Ministerstwa Obrony Narodowej, Warsaw 1973.

Radziwiłł A., Roszkowski W., Historia 1956-1997, Wydawnictwo Szkolne PWN, Warsaw 2000.

Sowa A.L., Historia polityczna Polski 1944-1991, Wydawnictwo Literackie, Krakow 2011.

Zaborowski Z., Podstawy wychowania zespołowego, Państwowe Wydawnictwo Naukowe, Warsaw 1967. 


\title{
Anita Grzegorzewska
}

\section{„Płomyczkowy” podręcznik dobrych manier jako przejaw strategii wychowawczych w socjalizmie}

\author{
Streszczenie
}

Artykuł podejmuje tematykę dobrych manier i wychowania w okresie PRL na przykładzie ówczesnej prasy dziecięcej i młodzieżowej. Autorka przeanalizowała 24 numery pisma Płomyczek z 1968 r. przy użyciu literatury z zakresu dydaktyki, strategii wychowawczych, a także etykiety i savoir-vivre. Abstrahując od zagadnień propagandy i ideologii, wzbogaciła swą analizę o historię polityczną Polski z okresu „małej stabilizacji”.

Słowa kluczowe: Dobre maniery, wychowanie, prasa dla dzieci, PRL, polityczna historia Polski

\section{Płomyczek's handbook on good manners as a manifestation of upbringing strategies under socialism}

Summary

The article raises the topic of good manners and upbringing in the People's Republic of Poland using the example of children's and young adult press from the period. The author analysed 24 issues of Płomyczek from 1968 considering literature in education, upbringing strategies, and etiquette. Leaving aside the issues of propaganda and ideology, she enriched the analysis by considering the political history of Poland during the period of the "minor stabilisation".

Keywords: good manners, upbringing, children's press, the People's Republic of Poland, Poland's political history. 
Anita Grzegorzewska - lecturer at the Department of Journalism and Social Communication at the University of Lodz. She researches linguistics, prosody and social communication issues such as PR, language pragmatics, and non-verbal communication. She is also interested in anthropology as well as cultures (ancient and contemporary) and religions. She is the author of the theory of communication prosody. She published a lot of articles on widely understood issues of social communication. 